\title{
THE ROMA AND OTHER ISTRIAN RESIDENTS' OPINIONS ABOUT SOME ASPECTS OF THE LEVEL OF INFORMATION OF THE PUBLIC BY THE POLICE IN THE CONTEXT OF EDUCATION AND ETHNIC DISCRIMINATION
}

\author{
Mirjana Radetić-Paić, PhD \\ Department of Preschool and Primary Education \\ "Juraj Dobrila" University in Pula (Croatia) \\ e-mail: mradeticpaic@ hotmail.com
}

\begin{abstract}
S u m m ary
This paper starts from the assumption that the Roma, as members of a specific minority group in Istria, will be discriminated in many ways by other citizens, less satisfied with the protection offered to them by the society and so express different opinions about the level of information of the public by the police. The general aim of this paper would, thus, be to gain an insight in the opinions of the Roma and other Istrian residents about some aspects of the level of information of the public by the police.

The sample is made of 200 members of the minority group of the Roma residents of the Istrian County and 200 other residents of the same country.

The results show that there are differences in the opinions of the Roma and other Istrian residents about some aspects of the level of information of the public by the police. However, these differences were not shown as significant.

The importance of the education of the Roma is pointed out in the paper. It should become a possible intercultural medium of their integration, lower assimilation, reinforcement of cultural autonomy and accessibility to various services and information.

Key words: the Roma, other residents of Istria, level of information, the police, education, ethnic discrimination
\end{abstract}

\section{Introduction}

In the Republic of Croatia, as well as in other countries they live in, the Roma are marginalized to a higher or lower extent because of their low education, noninclusion in formal forms of work, specific way of life and other characteristics (Šućur, 2000). They are not included in the social life which is manifested in various spheres, among others in education and access to different services and information.

19 
The Constitution of the Republic of Croatia (2001), The Constitutional Law about Minority Rights (2002), the National Programme for the Roma (2003) and the Action Plan of the Decade for the Inclusion of the Roma 2005.-2015. (http://www.vlada.rh/nacionalniprogramromi/Clanak_APD/-16k-) give the minorities the right of equality, universal development, nondiscrimination, identity, culture, religion, upbringing and education of children on their mother tongue and script and other important rights.

On the one hand, the duty of education in the contemporary society is to keep one's own national identity. In the Republic of Croatia, which tends to become a democratic European society, education has an important role of informing and forming the young as active and responsible members of the community they live in. (ČačićKumpes, 2004).

The European Union pays in the last fifteen years special attention to the problem of the Roma (Hrvatić, 2000, 2004). Conceptual documents and measures for the restructure of the socio-political and educational position of the Roma by integrating their language and culture and keeping the unity in the European education system are brought. All this is carried out by adapting administrative regulations to the needs of the Roma population on both the state and local level. In this way education becomes a possible intercultural medium for their integration, lower assimilation and reinforcement of cultural autonomy. Small steps have been made till now for adapting educational programmes and training teachers for working with children belonging to members of the Roma minority group. The realization of education of the Roma is inconsiderable and the theoretical explication poor. The possibility of making connections between school success and a better economical or social status is also evident, and the need for the education of adults is indicated.

Following all the formerly mentioned it can be concluded that minority groups can not dispose of the same amount of information (general information, specific information belonging to some knowledge) as the "general" population, i.e. the amount and structure of the level of information is to a higher extent defined by sociodemographic characteristics like their residence, gender, age, education, and others.

On the other hand, it can be concluded that the Roma as a minority group in Istria are not satisfied with the protection offered to them by the society, and the reason for this is that they are a specific minority group. Citizens of any local community have the need and the right for protection and safety, and if they do not feel so their engagement in cooperation with various institutions, especially the police, will fail to occur. This problem is emphasized with the members of the minority group of the Roma which is usually one of the main reasons for their non-cooperating in the initiatives of the community for their welfare. Other people usually do not understand their lifestyle and culture which leads to prejudices, marginalization and isolation. The specific way of life of this minority group (lack of conventional institutional education, families with more members than the average Croatian family, high birth rate, specific customs preserved till today in their original form, higher unemployment than for the other groups, being felt by other residents as a highly recognizable ethnic and cultural group, their culture not being accepted by other residents, great social distance and 
others) is even more manifested in a relatively homogenous society as the Croatian and so the prejudices and stereotypes are more expressed.

\section{The aim of the research and hypotheses}

This paper is part of the research project "The Police and the Protection of Vulnerable Groups: Minors, Women and Minorities" of the High Police School in Zagreb.

The general aim of this research is to gain an insight in the opinions of the Roma and other Istrian residents about some aspects of the level of information of the public by the police. The specific aims are to obtain an insight into the visits to the HomeOffice web pages, the opinions about the level of information of the public by the police about police procedures, into the advice about protection from crime, into difficulties inside the police, and into possibilities for citizens' complaints.

Following this, a general hypothesis has been set by which differences in opinions of the Roma and other Istrian residents about some aspects of the level of information offered by the police are shown. The following sub-hypotheses are included in the main one:

$\mathbf{H}_{21}$ : it is assumed that the Roma will visit the Home-Office web pages less than other Istrian residents;

$\mathbf{H}_{22}$ : it is assumed that the Roma will have a different opinion about the level of information of the public by the police about the regulations for police procedures than other Istrian residents;

$\mathbf{H}_{23}$ : it is assumed that the Roma will have a different opinion about the level of information of the public by the police about the advice for the protection from crime than other Istrian residents;

$\mathbf{H}_{\mathbf{2 4}}$ : it is assumed that the Roma will have a different opinion about the level of information of the public by the police about difficulties inside the police than other Istrian residents;

$\mathbf{H}_{25}$ : it is assumed that the Roma will have a different opinion about the level of information of the public by the police about the possibilities for citizens' complaints.

In general, the paper started from the assumption that the Roma, as members of a specific minority group in this area, will be discriminated by other residents in many ways and expresses different opinions about the level of information of the public in the widest sense, especially by the police. Recent foreign researches (Bowling, 1999; Ogawa, 1999; Levin, 2002) show that members of ethnic minorities are less satisfied with the police procedure when compared to opinions from other residents, which can influence their opinion about the level of information by the police. 


\section{Methods}

\section{Sample of examinees}

The sample is made of 200 members of the minority group of the Roma resident in the Istrian County (the experimental group) and 200 residents of the Istrian County (control group). The sample of examinees is occasional. The Roma sample of examinees was chosen from the evidences of the Centres for Social Care of the Istrian County (Centre for Social Care in Pula, Buje, Rovinj, Poreč, Pazin and Labin) since it was estimated that these centres still have the most complete facts about the members of the national minority in question. It was also assumed that a large number of such members enjoy the rights of social care which was shown by recent researches. Namely, the research by the author Šucur (2005) confirms the fact that social help is the most usual source of income for the Roma, i.e. that in three fourths of households social help is the first or second source of income. Thus, in 2003 the evidences of the Centre for Social Care in Pula (which is in authority for the District of Vodnjan) showed that the Roma made one-third of the users of all material funds and that 53 families gained supportive help. Different measures for family and legal protection were pronounced in 30 cases.

The group of examinees belonging to other residents of the Istrian County $(\mathrm{N}=$ 200 ) is equalized according to gender, age and education to the group of the Roma, and mostly chosen from the evidences of the same centres since it is, along with the characteristics mentioned, very similar to the Roma group in their socio-economic circumstances (included in a kind of material protection). It was also chosen from the evidences of the Central Employment Office. The results will not be generalized on the whole population of the Roma or other residents, but still form an important insight in their opinions about some aspects of the level of information of the public by the police in the context of education and ethnic discrimination.

It should be emphasized that the right number of the Roma residents in Istria and their right territorial position is difficult to define, and so the results of the formal census are just a glimpse into the real state of things. Some authors (Acrap and partners, 1998; Zoon, 2002) point out the fact that the Roma in the Republic of Croatia make 0.14 percent of the whole population. According to the census of 1991, there were 637 members of the Roma society in the Istrian County which was something less than 10 percent of the whole number of the Roma in the Republic of Croatia for the same year. The census of 2001 showed that in the Istrian County there were 600 members of the Roma society. The same census made evident that most of the Roma lived in the south of Istria, in the towns of Pula and Vodnjan. According to the census, in Pula there were 301, and in Vodnjan 195 members of the Roma minority group (The National Programme for the Roma, 2003).

Chart 1 shows the distribution of examinees according to their residence in the Istrian County. It is evident that the examinees mostly live in the area of the towns of Pula and Vodnjan. Just a smaller number of them were registered in other, mostly smaller districts. 
Chart 1 The distribution of examinees according to their residence

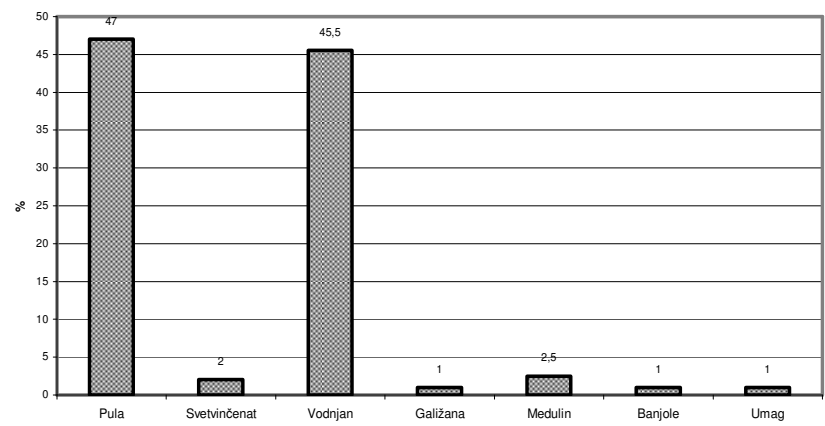

Chart 2 The distribution of examinees according to gender

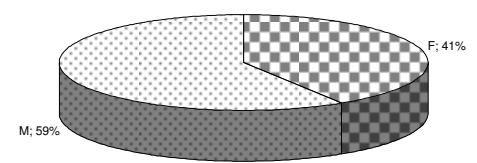

The research included 59 percent of male and 41 percent of female examinees (Chart 2). When it comes to members of the minority group of the Roma, it is known that in their families there is a traditional division of roles, women are often marginalized and subject to discrimination, associated with the household, and their lower participation in the sample of examinees can be thus explained. All is reflected in the upbringing of children and in the functioning of the family and indirectly in education and the level of information.

Chart 3. The distribution of examinees according to age

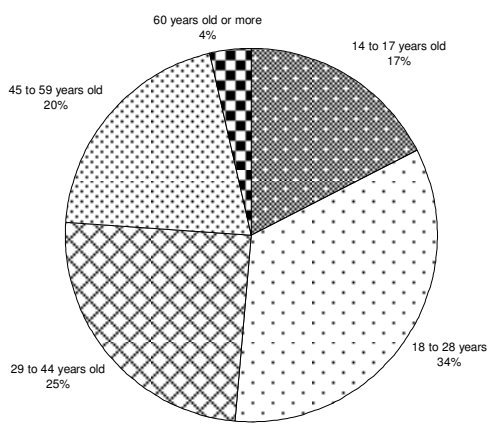

Most of the examinees were from 18 to 28 or from 29 to 44 years old (almost $60 \%$ of them - Chart 3). 
Chart 4 The distribution of examinees according to their education

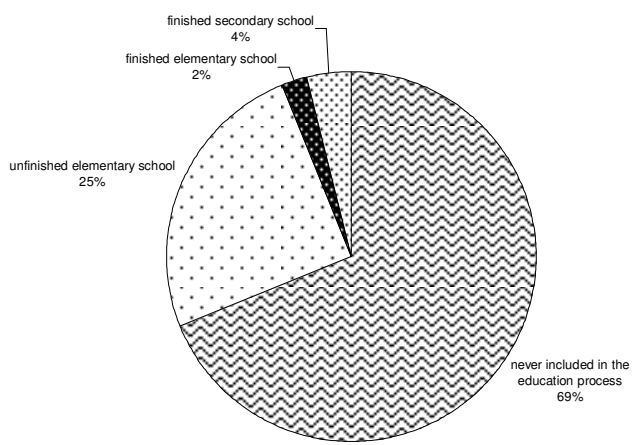

The educational status of examinees included in the sample is, as expected, relatively low (Chart 4.) It can be seen that almost 70 percent of examinees are not included in the education process. It is interesting and encouraging that those who entered elementary school almost always finished it. Only four percent examinees have a secondary school education, and none of them has a university degree.

\section{The sample of variables and data processing}

The questionnaire has been made in cooperation with the Study group for planning, implementation and monitoring of the "Police in the community" Strategy, the Study group for planning, implementation and monitoring of the project Organization of municipal prevention and the OESS mission in Croatia. Variables which describe some aspect about the level of information of the public by the police were used for the needs of this paper: visits to the Home-Office web pages, opinions about the level of information of the public by the police about the regulations for police procedures, about the advice on protection from crime, about difficulties inside the police and about possibilities of citizens' complaints.

The $\chi^{2}$ test, along with the working out of marginal frequencies, was used in data processing.

\section{Carrying out the research}

The research was carried out during 2004 and 2005 in cooperation with the Association of the Roma of the Istrian County and the Centres for Social Care in Pula, Buje, Rovinj, Pazin and Labin, in such a way that each examinee, member of the Roma or other Istrian residents group filled in a questionnaire. Some examinees needed the help of professionals since they were insufficiently literate or did not understand some 
notions. All the questionnaires in this research are anonymous and used exclusively for the needs of this scientific research.

\section{Results and discussion}

Table 1 shows that in $78.5 \%$ of cases the Roma did not visit the Home Office web pages because they did not have the access to the Internet. Other Istrian residents do not have access to the Internet in $67.5 \%$ of cases. Based on these indicators it is evident that the examinees do not visit the Home-Office web pages. 20 percent of them say that they do not visit the web page because it is of no interest to them. There can be many reasons for this, but it is assumed that the most important one is their not possessing a personal computer or poverty. This is confirmed by a quantitative research on a general population ( $\mathrm{N}=8534)$ included in the project "Life Quality and the Risk for Social Exclusion in the Republic of Croatia." It included all the counties (United Nations Development Programme Croatia, 2006), and it showed that something less than half of the households in the Republic of Croatia own a personal computer. Examinees not owning a personal computer stated more often that they did not need it instead of not being able to afford one. As it was expected in the research, households owning a personal computer have higher incomes than those not owning it. Residents of rural areas own a personal computer more rarely than those from urban centres.

By working out the $x^{2}$ test, the value of 34.346 is obtained. With the third degree of freedom on the level of significance of 0.05 , the marginal value of the test is 7.815 , so these indicators can be taken as significant, not occasional.

Table 1 Visits to the Home-Office web pages

\begin{tabular}{|c|c|c|c|c|c|c|c|}
\hline \multicolumn{2}{|c|}{} & \multicolumn{2}{|c|}{ all } & \multicolumn{2}{c|}{ the Roma } & \multicolumn{2}{c|}{$\begin{array}{c}\text { Other } \\
\text { residents }\end{array}$} \\
\hline variable & cathegory & ap. & $\%$ & ap. & $\%$ & ap. & $\%$ \\
\hline all & 400 & 100,00 & 200 & 100,00 & 200 & 100,00 \\
\hline & I have visited it & 3 & 0,75 & 0 & 0,00 & 3 & 1,50 \\
\cline { 2 - 9 } $\begin{array}{c}\text { you have not } \\
\text { visited the } \\
\text { home-office } \\
\text { web page }\end{array}$ & $\begin{array}{c}\text { I do not have } \\
\text { access to the } \\
\text { internet }\end{array}$ & 270 & 67,50 & 157 & 78,50 & 113 & 56,50 \\
\cline { 2 - 9 } & $\begin{array}{c}\text { I do not know the } \\
\text { address }\end{array}$ & 33 & 8,25 & 3 & 1,50 & 30 & 15,00 \\
\cline { 2 - 9 } & I am not interested & 94 & 23,50 & 40 & 20,00 & 54 & 27,00 \\
\hline
\end{tabular}

$$
\chi^{2}=34,346 ; d f=3 ; p=0,000
$$

It can be noticed that $60 \%$ of the Roma think that the police (probably or absolutely) do not inform the public about the regulations for their procedures (Table 2 ), and this is the opinion of almost the same number of other Istrian residents. The 
sources for such opinions can be found in poverty, cultural or educational marginalization and social exclusion. As it has already been mentioned, the basic characteristic of social exclusion is not participating in the social life which is reflected in the sphere of education. Here it is a question of the Roma opinion that the public is uninformed about this problem. At the same time, the question about how the Roma expect the public to be informed can be posed, if taken into consideration all the formerly mentioned characteristics of their social exclusion and marginalization. However, it is undisputable that the Roma minority members recognized the problem of the lack of information of the public by the police when it comes to their own procedures regulations.

The $\chi^{2}$ test gives the value of 9.185 and it is higher than the marginal value on the third level of freedom (7.815) which means that the indicators can be taken as significant, not occasional.

Table 2 Level of information about the regulations for police procedures

\begin{tabular}{|c|c|c|c|c|c|c|c|}
\hline \multicolumn{2}{|c|}{} & \multicolumn{2}{|c|}{ all } & \multicolumn{2}{|c|}{ the Roma } & \multicolumn{2}{c|}{$\begin{array}{c}\text { Other } \\
\text { residents }\end{array}$} \\
\hline variable & cathegory & ap. & $\%$ & ap. & $\%$ & ap. & $\%$ \\
\hline all & 400 & 100,00 & 200 & 100,00 & 200 & 100,00 \\
\hline $\begin{array}{c}\text { the police offer } \\
\text { sufficient }\end{array}$ & absolutely yes & 8 & 2,00 & 5 & 2,50 & 3 & 1,50 \\
\cline { 2 - 9 } $\begin{array}{c}\text { information to } \\
\text { the public } \\
\text { about their } \\
\text { procedure } \\
\text { regulations }\end{array}$ & probably not & 178 & 44,50 & 77 & 38,50 & 101 & 50,50 \\
\cline { 2 - 9 } & absolutely not & 46 & 11,50 & 20 & 10,00 & 26 & 13,00 \\
\hline
\end{tabular}

$$
\chi^{2}=9.185 ; d f=3 ; p=0.027
$$

Table 3 Level of information about the advice for protection from crime

\begin{tabular}{|c|c|c|c|c|c|c|c|}
\hline \multicolumn{2}{|c|}{} & \multicolumn{2}{|c|}{ all } & \multicolumn{2}{c|}{ the Roma } & \multicolumn{2}{c|}{$\begin{array}{c}\text { other } \\
\text { residents }\end{array}$} \\
\hline variable & cathegory & ap. & $\%$ & ap. & $\%$ & ap. & $\%$ \\
\hline all & & 400 & 100,00 & 200 & 100,00 & 200 & 100,00 \\
\hline $\begin{array}{c}\text { the police offer } \\
\text { sufficient information } \\
\text { to the public about the } \\
\text { advice on protection } \\
\text { from crime }\end{array}$ & absolutely yes & 7 & 1,75 & 4 & 2,00 & 3 & 1,50 \\
\cline { 2 - 10 } & probably yes & 207 & 51,75 & 94 & 47,00 & 113 & 56,50 \\
\cline { 2 - 9 } & probably not & 146 & 36,50 & 87 & 43,50 & 59 & 29,50 \\
\hline
\end{tabular}

$\chi^{2}=9,757 ; d f=3 ; p=0,021$ 
Other Istrian residents think that they are more sufficiently informed about the protection from crime than the Roma (Table 3). It is assumed that such indicators have their source in the lack of confidence of the Roma in institutions, especially the police. Namely, knowledge about the higher victimization of some minority groups are specially significant since the experience of victimization by extremistic violence, and especially the reaction of the society to such a personal experience, highly affect the way members of ethnic, racial, religious or any other groups, who are the objects of assault think, feel and act in the social community. This phenomenon affects the choice of residence, working place, and the place for spending their free time. Members of such, usually minority groups are afraid of violence on their life and entity and are not satisfied with the protection offered by the society. This is why they usually organize themselves, which usually represents the source for new violence (Cajner Mraović and Mraović, 2000).

The result of the $\chi^{2}$ test is 9.757 and it is higher than the marginal value on the third degree of freedom (7.815), which means that the indicators can be taken as significant, not occasional.

Table 4 Level of information about difficulties inside the police

\begin{tabular}{|c|c|c|c|c|c|c|c|}
\hline \multicolumn{2}{|c|}{} & \multicolumn{2}{|c|}{ all } & \multicolumn{2}{c|}{ the Roma } & \multicolumn{2}{c|}{$\begin{array}{c}\text { other } \\
\text { residents }\end{array}$} \\
\hline variable & cathegory & ap. & $\%$ & ap. & $\%$ & ap. & $\%$ \\
\hline all & & 400 & 100,00 & 200 & 100,00 & 200 & 100,00 \\
\hline $\begin{array}{c}\text { the police offer } \\
\text { sufficient } \\
\text { information to the } \\
\text { public about } \\
\text { difficulties inside } \\
\text { the police }\end{array}$ & absolutely yes & 10 & 2,50 & 5 & 2,50 & 5 & 2,50 \\
\cline { 2 - 9 } & probably yes & 149 & 37,25 & 58 & 29,00 & 91 & 45,50 \\
\cline { 2 - 9 } & absolutely not & 72 & 18,00 & 42 & 21,00 & 30 & 15,00 \\
\hline
\end{tabular}

$\chi^{2}=11,918 ; d f=3 ; p=0,008$

In general, $70 \%$ of the Roma think that they are not informed about the difficulties inside the police (Table 4.). Other Istrian residents are divided in their evaluations.

The $\chi^{2}$ value of 11.918 is higher than the marginal value on the third level of freedom (7.815), which means that the indicators can be taken as significant.

About one third of the Roma think that the police inform the public about possibilities for their complaints sufficiently. Other evaluations are about an insufficient level of information (Table 5.). The reasons for such evaluations can here be also found in the liability of the Roma as a minority subjective opinion about their discrimination compared to other Istrian residents who express more positive opinion.

The value of the $\chi^{2}$ test is 12.943 and it is higher than the marginal value on the 
third degree of freedom (7.815), which means that the indicators can be taken as significant, not occasional.

Table 5 Level of information about the possibilities for citizens' complaints

\begin{tabular}{|c|c|c|c|c|c|c|c|}
\hline \multicolumn{2}{|c|}{} & \multicolumn{2}{|c|}{ all } & \multicolumn{2}{c|}{ the Roma } & \multicolumn{2}{c|}{$\begin{array}{c}\text { other } \\
\text { residents }\end{array}$} \\
\hline variable & cathegory & ap. & $\%$ & ap. & $\%$ & ap. & $\%$ \\
\hline all & 400 & 100,00 & 200 & 100,00 & 200 & 100,00 \\
\hline $\begin{array}{c}\text { the police offer } \\
\text { sufficient } \\
\text { information to the } \\
\text { public about the } \\
\text { possibilities for } \\
\text { citizens' } \\
\text { complaints }\end{array}$ & absolutely yes & 10 & 2,50 & 7 & 3,50 & 3 & 1,50 \\
\cline { 2 - 9 } & probably yes & 153 & 38,25 & 60 & 30,00 & 93 & 46,50 \\
\cline { 2 - 9 } & absolutely not & 61 & 15,25 & 37 & 18,50 & 24 & 12,00 \\
\hline
\end{tabular}

$\chi^{2}=12,943 ; d f=3 ; p=0,005$

\section{Conclusion}

By the indicators obtained it is possible to assume that there are differences in the opinion of the Roma and other Istrian residents about some aspects of the level of information of the public by the police, and so the general hypothesis and the subhypotheses can be accepted. However, these differences are not distinct (just 8\%).

It is probable that the negative opinions of the Roma are influenced by some other factors, not just the opinions and attitudes about some aspects of the level of information by the police. It can be assumed that here it is a question of the influence of the Roma negative experiences linked to their ethnic discrimination. The police, seen by the Roma as having sometimes positive characteristics, do not reflect these characteristics in their procedures because here they reflect some of their own attitudes which can also be negative toward the Roma as an ethnic minority.

It can be concluded that the level of information is under immense influence of various factors; some are linked to the family, some to the wider environment, and education has an important role in this.

As it is known (Zidarić, 1994; Korpar, 1996; Hrvatić, 2000; Štambuk, 2000) the school realization of upbringing and education of Roma children in Croatia is insignificant. It is needed, and also defined by the national policy of the Republic of Croatia (The Constitution of the Republic of Croatia, The Constitutional Law about National Minority Rights, The Law about the Upbringing and Education on the Language and Script of the National Minority, the National Programme for the Roma, the working programme of the Republic of Croatia National Minority Council) to restructure the social-political and educational position of the Roma on a global level, 
by integrating their language and culture. Education would, thus, become a possible intercultural medium for their integration, lowering assimilation, reinforcing cultural autonomy and access to various services and information.

\section{Bibliography}

AKRAP, A. GELO, J. and GRIZELJ, M. (1998), The Move of the Total Number of Residents of the Republic of Croatia since the Census of 1991 to 1998 and Quantification of some Components. Zagreb: The Institute for Social Studies "Ivo Pilar".

BOWLING, B. (1999), Violent Racism: Victimisation, Policing, and Social Context. Clarendon Studies in Criminology. Oxford: Oxford University Press.

CAJNER MRAOVIĆ, I. and MRAOVIĆ, A. (2000), Extremistic Violence: Some Basic Questions about the Fenomenology, Ethiology and Fighting the Phenomenon. The Police and Safety. 3-6, 9, 174-186.

ČAČIĆ-KUMPES, J. (2004), Interculturality in Education: Concepts and Developmental Possibilities. History in Education. Croatian Society for Historical. 2, 4, 305-321.

KORPAR, V. (1996), Methods of Education of the Roma Children. II Council in Upbringing and Education of the Roma in Croatia: collected presentations - Križevci. The Alliance of Associations of the Croatian Roma. Pgs.22-24.

LEVIN, J. (2002), The Violence of Hate: Confronting Racism, Anti-Semitism, and Other Forms of Bigotry. Allyn \& Bacon. Boston.

HRVATIĆ, N. (2000), Upbringing and Education of the Roma in Croatia. Social Studies. Zagreb. 9, (2-3. 46-47), 267-290.

HRVATIĆ, N. (2004), The Roma in Croatia: from Migrations to Intercultural Relations. Migrational and Ethnic Themes. Zagreb. 20, 4, 367-385.

OGAWA, K. B. (1999), Colour of Justice: Culturally Sensitive Treatment of Minority Crime Victims. California: Allyn and Bacon.

ŠTAMBUK, M. (2000), The Roma in the Croatian Social Area. Social Studies, Zagreb, 9, (23, 46-47), 197-210. 211-227.

ŠUĆUR, Z. (2000), The Roma as a Marginal Group. Social Studies. Zagreb. 9, (2-3, 46-47),

Šućur, Z. (2005) Poverty as the Component of the Socio-cultural Identity of the Roma. In: Maja Štambuk (ed.) How Do Croatian Roma Live. Zagreb. The institute for Social Sciences "Ivo Pilar," pgs. 133-158.

The Action Plan of the Decade for the Roma Inclusion 2005-2015

(http://www.vlada.rh/nacionalniprogramromi/Clanak_APD/-16k-), 26.10.2008.

The Constitution (2001) Consolidated Text. "Narodne novine" NO.41.

The Constitutional Law about National Minority Rights (2002) "Narodne novine" No. 155.

The National Programme for the Roma (2003), The Government of the republic of Croatia

United Nations Development Programme Croatia (2006), The Quality of Life in the Republic of Croatia and the Risk for Social Exclusion. Research Project. Target Ltd. Market and Public Opinion Research. European Foundation for the improvement of Living and Working Conditions. Dublin. Ireland.

ZIDARIĆ, V. (1994), Current Questions about the Education of the Roma in Countries 29 
Members of the European Union. In: Hrvatić, N. (ed.) Upbringing and Education of the Croatian Roma's Children: collected papers - Macinec. The Alliance of Associations of the Croatian Roma, pgs.76-81.

ZOON, I. (2002), Report on obstacles facing the Roma minority of Croatia in accessing different categories of rights and namely citizenship, housing, health and social assistance, Roma under the Stability Pact. Concil of Europe - European Commission.

Metodički obzori 9; vol. 5(2010)1

Prethodno priopćenje

UDK: $37.015 .4: 376.7$

Primljeno: 21. 2. 2010.

\title{
MIŠLJENJA ROMA I OSTALOG STANOVNIŠTVA ISTRE O POJEDINIM ASPEKTIMA INFORMIRANOSTI JAVNOSTI OD STRANE POLICIJE U KONTEKSTU OBRAZOVANJA I ETNIČKE DISKRIMINACIJE
}

\author{
Dr. sc. Mirjana Radetić-Paić \\ Odjel za obrazovanje učitelja i odgojitelja, \\ Sveučilište Jurja Dobrile u Puli \\ e-mail: mradeticpaic@hotmail.com
}

Sažetak

U radu se polazi od pretpostavke da će Romi kao članovi specifične manjinske skupina na području Istre biti u mnogočemu diskriminirani od ostalog stanovništva, manje zadovoljni zaštitom koju im društvo pruža, pa samim tim i izražavati različita mišljenja o informiranju javnosti od strane policije. Stoga je generalni cilj ovog rada steći uvid u mišljenja Roma i ostalog stanovništva Istre o pojedinim aspektima informiranosti javnosti od strane policije.

Uzorak čine 200 pripadnika manjinske skupine Roma s prebivalištem na području Istarske županije i 200 stanovnika Istarske županije.

Rezultati pokazuju da postoje razlike u mišljenjima Roma i od strane ostalog istarskog stanovništva o pojedinim aspektima informiranosti javnosti od strane policije, međutim, te se razlike nisu pokazale velikim.

U radu se ističe važnost obrazovanja Roma koje bi trebalo postali mogući interkulturalni medij u funkciji njihove integracije, smanjenja asimilacije, jačanja kulturne autonomije odnosno pristupa različitim uslugama i informacijama.

Ključne riječi: Romi, ostalo stanovništvo Istre, informiranost, policija, obrazovanje, etnička diskriminacija 